\title{
Digital Marketing Usage and Measurement in Turkey
}

\author{
Ph.D. Candidate Barış Batuhan Geçit (Beykent University, Turkey) \\ Prof. Dr. Erdoğan Taşkın (Beykent University, Turkey)
}

\begin{abstract}
Technological advances force firms to adapt new strategies and be more innovative. As firms changed their strategies, they also had to change their marketing strategies. There has been the necessity of surviving and obtaining more competitive advantage as world advance. In order to gain competitive advantage, marketing strategies should have been applied more technologically. This made firms adapt to the concept of digital marketing. Digital marketing is simply the application of marketing tools via digital or technological devices.

This research focuses on exploring the digital marketing issue that is evolving through virtual connections. For this purpose hypothesis related to digital marketing has been tested on this study and survey method has been applied to marketing managers in Turkey. A survey with five-likert scale has been conducted.

According to the results obtained from survey, managers see measurement of digital marketing important and see lack of knowledge and difficulty of content creating as the biggest barriers for using digital marketing.
\end{abstract}

\section{Introduction}

As technology continues to dominate and rule the World, business world has been forced to adapt to the technological advances. Business, economics, communication and most social sciences has been adapting to the technological advances for decades. Even political science discipline has adapted to the technology with the concepts like E-Democracy. So as a sub branch of business administration discipline, marketing discipline has felt the necessity of adapting to the technological advances.

Marketing discipline was required to adapt to the global technological advances. Today most of the promotion tools are applied utilizing technological tools. Instead of using classical tools such as newspapers, billboards..etc; digital marketing tools are more intensively utilized by the marketing professionals. So digital marketing has become an indispensable tool to create marketing communication.

Digital marketing concept first appeared in 1990s but world has changed a lot since then. Firstly there was Web 1.0 which was static and with very little interaction and communities. In 1994, Search Engine Optimization has begun with the introduction of first banner advertising (Kingsnorth, 2016, p.7).

After couple of years Google started to grow rapidly and Blogger was launched. Google's introduction of Adwords was their real platform for growth and remains a key revenue stream for them to this day. Their innovation, simple interface and accurate algorithms continue to remain unchallenged (Kingsnorth, 2016, p.7).

Web 2.0 was a term coined in 1999 by Darcy DiNucci but not really popularized until Tim O'Reilly in 2004. With Web 2.0 there was no over- haul of technology as the name might suggest, but more a shift in the way that websites are created. This allowed the web to become a social place, it was an enabler for online communities and so Facebook, Twitter, Instagram, Pinterest, Skype and others were born (Kingsnorth, 2016, p.7).

The concept of Web 3.0, as it is imagined by business models and Web developers, is often associated with the idea of the Semantic Web. Floridi (2009) contended that the Semantic Web as portrayed by Tim Berners-Lee and the people of the W3C (World Wide Web Consortium) is not feasible either technically (at least not yet) or socially, but he argues that the Web is developing well beyond the interactive processes of Web 2.0 in a variety of different ways. The understanding of Web 3.0 as a site of user cooperation can also be found in the work of Fuchs (2008). For him Web 3.0 is created by 'networked digital technologies that support human cooperation' (2008, p.127). This focus on cooperation can be problematic (Barassi and Tere, 2012, p.1273).

Today most of the trade across the World is being done by virtual networks, which connects firms and people. Related digital technologies increased the change in marketing communication industry and created a dowel action (Fill, 2006).

Advances in virtual marketing field and other high technologies has changed the relationship between consumers and marketing professionals dramatically. No other power is more effective than technology in terms of marketing strategy and application (Kotler and Armstrong, 2014: 47). 


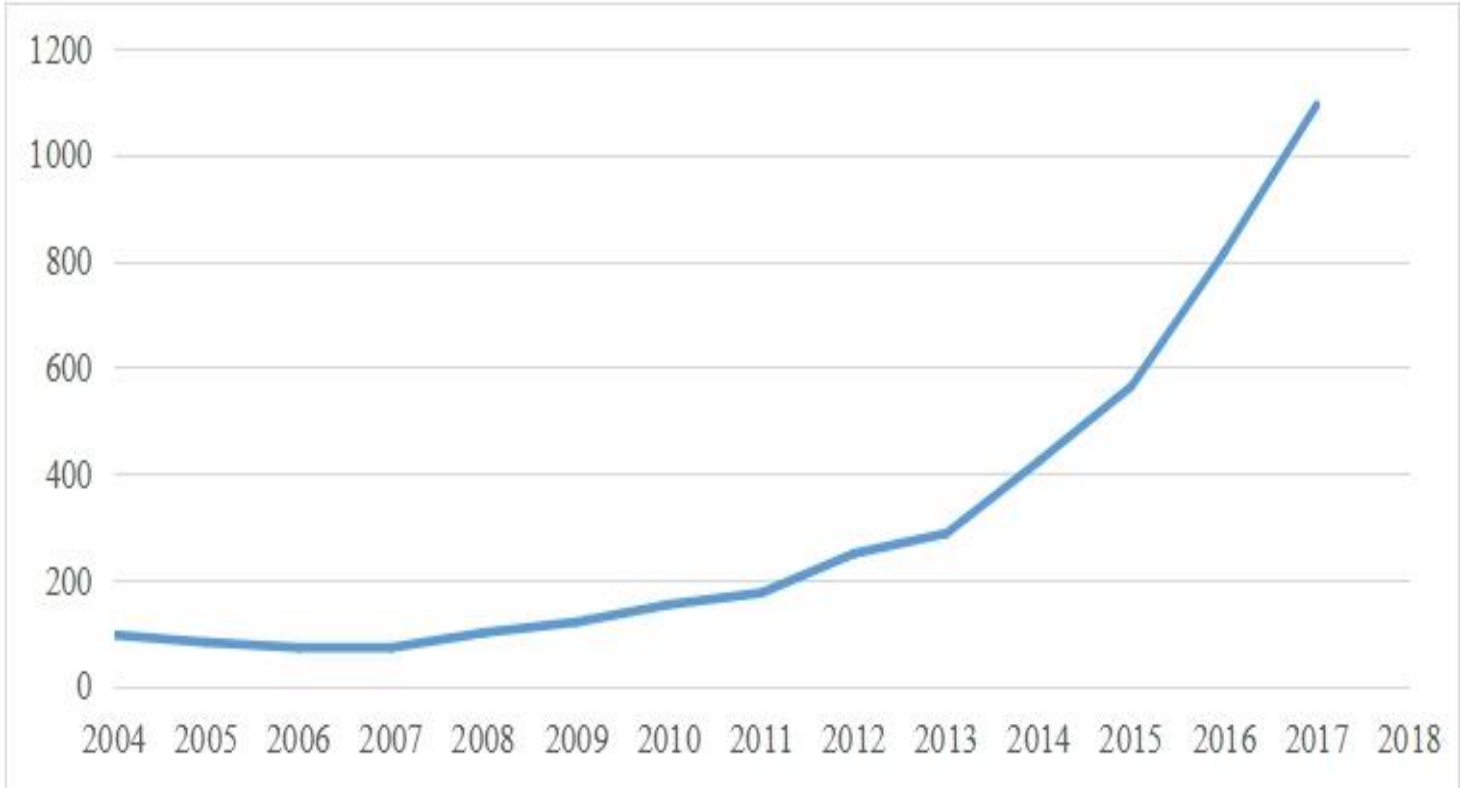

Figure 1. Increase of Digital Marketing

Digital marketing is one of the most important topics related to marketing. According to Google Trends, google searches of digital marketing keyword from 2004 to 2018, there is a rapid increase on digital marketing keyword from 2011 to 2018. This increase can be seen at the Figure 1. which has a huge upwards slope from 2011 to 2018. This graph shows how important digital marketing became and the increasing importance trend of digital marketing from year to year (https://trends.google.com.tr/trends/08.03.2018).

Managers are confident on digital marketing to build their brand ( $82 \%$ of surveyed managers rated it as important or extremely important), improve knowledge ( $78 \%$ of managers), and heighten communication flows ( $70 \%$ of managers). As social networks are widely based on user participation, it is reasonable to expect that the promotion of social activities would emerge as a key motivator for firms to become involved with social media (Tiago and Verissimo, 2014, p.705).

With the advances in new virtual marketing tools and online technologies, use of online social networks and marketing created by consumers has booms (Kotler and Armstrong, 2014, s.47).

Digital marketing has four basic concepts: Acquire, Convert, Measure and Optimise, Retain and Grow. To define these concepts (Öçal, 2011):

- Acquire: Main purpose is to gain consumers to your website. Search Engine Optimisation (SEO), Search Engine Commercials (PPC), E-Mail Marketing, Social Media Marketing, Affiliate Marketing, Interactive Comparison, Advertising Partnership, Viral Marketing, Content Production, RSS, Online PR are some of the main topics.

- Convert: Activities that enable websites to reach its purposes after consumer visits website. Main purpose is not always selling. Blog reading numbers, number of likes, number of shares and followers are also important for the website.

- Usability and accessibility, Customer Decision Support, content management, site usefulness enhancement, sales text convincing writing, personalization, customer segment identification and targeting (Personalization, Segmenting, Targeting), Email Marketing, duplication of payment options and improvement of the on-site search are the main activities to be done at this stage.

- Measure and Optimize: In this step, firms learn what they are doing correct or wrong and helps firms to compare themselves with their rivals.

Web analytics software should be used to evaluate the activities performed in the acquire and convert sections and determine where to optimize according to the results. Competitor Benchmarking, Online Panels and Online Surveys, Usability Testing, A / B Testing, Multivariate Testing should be done to measure and optimize.

\section{Importance of Digital Marketing}

Today, marketers use interrelated digital marketing tools and a variety of techniques to make customer positioning. In addition, management is taking advantage of digital marketing methods to create customer value in general, improve competitive offerings, communicate more and direct positive experience and advice (Dipp et al., 2012). 
Digital marketing methods include web site, online public relations, electronic mail, blogs, microblogs, social networks, wiki's, podcasts and search engine management to provide preferential research. For marketers, there are disadvantages resulting from the widespread use of digital marketing applications (Tiago and Verissimo, 2014, p.705).

Tiago and Verissimo (2014) claims that digital and social media brings several advantages to firms; such as publishing, online sales, market research, customer support, brand building, creating word of mouth marketing and improving firms' overall performance. According to a research conducted on managers in Portugal about digital marketing; external competitive pressure plays the most prominent role in a firm's decision to utilize digital media for marketing purposes (\%56 of managers have rated it as important) (Tiago and Verissimo, 2014, p.705).

Digital marketers use many new options to attract attention of potential customers and maintain relationships with existing ones. In addition, digital marketing offers opportunity to present far more information to all consumers instantly. It also immediately provides the opinions of experts to all consumers. The digital media has removed this function in the majority of marketers who have previously had control over the brands and the issues reported to the customers about their products. Nonetheless, digital media is one of the most exciting changes that marketers have faced for centuries. Firstly, an individual contact was established with millions of potential and existing customers in each geography, or with only one customer. Marketers are immediately updating different suggestions and messages to detect all these new developments or to understand the challenges in the market (Dipp et al., 2012).

\begin{tabular}{|l|c|}
\hline Benefit Type & $\mathbf{\%}$ \\
\hline Improves information gathering and feedback & 87 \\
\hline User-friendly tool & 85 \\
\hline Increases knowledge & 85 \\
\hline Promotes internal and external relationships & 82 \\
\hline Supports decision-making process & 60 \\
\hline Increases productivity & 58 \\
\hline Better outcome measurement & 53 \\
\hline Percentage of respondents rating 4 or 5 on a scale 1-5 scale where 5=extremely important. $N=170$
\end{tabular}

\section{Table 1. Benefits of Digital Marketing}

According to Table 2. which has been applied to managers; Improvement in information gathering and feedback is the most important benefit of digital marketing with \%87 percent. User friendly tools and increases knowledge share the second most important benefits slot with \%85 percent. Promoting internal and external relationships is fourth with $\% 82$ percent. Supporting decision making process has $\% 60$ percent, increases productivity has $\% 58$ and better outcome measurement has \%53 percent (Tiago and Verissimo, 2014, p.705).

The study conducted by Tiago and Verissimo (2014) definitely shows the aspects that make digital marketing important for managers. As survey results show, digital marketing creates so many advantages for managers and their firms' and digital marketing will continue its fare of being the indispensable concept of marketing.

\section{Methodology}

A survey has been conducted to marketing managers in Turkey to find out and measure the usage of digital marketing. A scale has been used by Järvinen and etc. (2012) has been used for this purpose. Results obtained from the survey has been analyzed by using IBM SPSS 24 application.

\section{Analysis}

According to the Table 3. Normality analysis; Skewness and Kurtosis values of all questions are within the range of $-1,-2$ and $+1,+2$ which means values are showing normality.

\begin{tabular}{|c|c|c|}
\hline & Skewness & Kurtosis \\
\hline$\overline{\mathrm{Q} 1}$ & $-1,217,337$ & ,525 ,662 \\
\hline Q2 & $-, 779 \quad, 337$ & $\begin{array}{ll}-, 412,662\end{array}$ \\
\hline Q3 & $-, 502,337$ & $\begin{array}{ll}-, 561 \quad, 662\end{array}$ \\
\hline Q4 & $-, 566 \quad, 337$ & $\begin{array}{ll}-, 596,662 \\
-, 56\end{array}$ \\
\hline Q5 & $-, 808 \quad, 337$ & $\begin{array}{ll}-544,662\end{array}$ \\
\hline Q6 & $-, 423 \quad, 337$ & $-1,170,662$ \\
\hline Q7 & $-, 552,337$ & $\begin{array}{ll}-, 899,662\end{array}$ \\
\hline Q8 & $-, 496 \quad, 337$ & -,984, 662 \\
\hline Q9 & ,090 & $-1,578,662$ \\
\hline
\end{tabular}

Table 2. Normality Analysis 
Table 3. Frequencies Table I shows how much respondents agree with given ideas with the five likert scale. For the scale, 1 means the respondent strongly doesn't agree with the idea, 2 means that they don't agree with the idea, 3 means they don't agree or disagree, 4 means they agree with the given and 5 means they strongly agree with the given idea.

\begin{tabular}{|c|c|c|c|c|c|c|c|c|c|}
\hline & 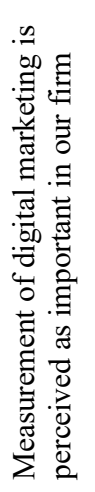 & 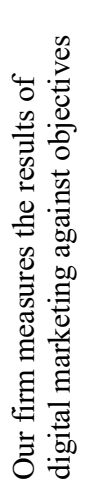 & 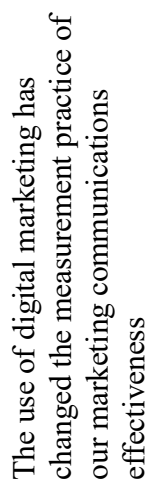 & 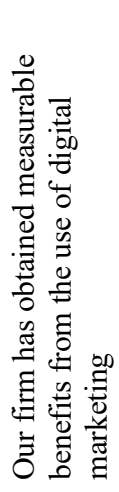 & 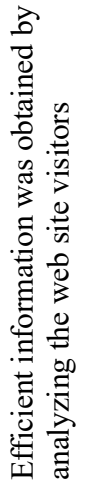 & 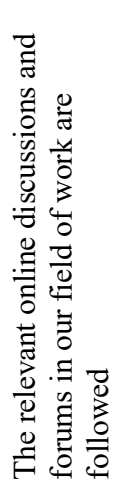 & 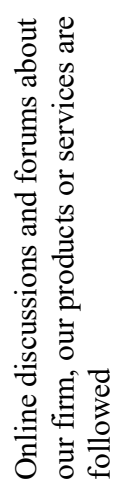 & 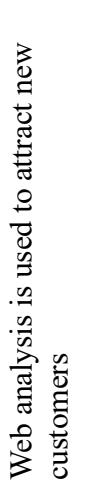 & 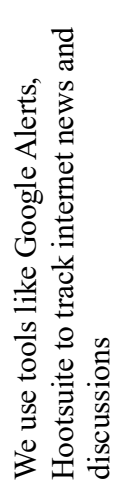 \\
\hline 1 & 6,0 & 12,0 & 6,0 & 4,0 & 16,0 & 14,0 & 12,0 & 14,0 & 34,0 \\
\hline 2 & 10,0 & 8,0 & 16,0 & 16,0 & 6,0 & 20,0 & 16,0 & 14,0 & 12,0 \\
\hline 3 & 6,0 & 16,0 & 22,0 & 16,0 & 12,0 & 8,0 & 14,0 & 18,0 & 14,0 \\
\hline 4 & 34,0 & 36,0 & 36,0 & 36,0 & 40,0 & 38,0 & 34,0 & 28,0 & 18,0 \\
\hline 5 & 44,0 & 28,0 & 20,0 & 28,0 & 26,0 & 20,0 & 24,0 & 26,0 & 22,0 \\
\hline Mean & 4,00 & 3,59 & 3,49 & 3,66 & 3,53 & 3,30 & 3,44 & 3,40 & 2,84 \\
\hline
\end{tabular}

Table 3. Frequencies Table I

Table 4. Frequencies Table II shows how much respondents agree with the ideas as usage barriers for digital marketing. For each question five-likert scale has been used. For the scale, 1 means the respondent strongly doesn't agree that the given idea is a barrier for usage of digital marketing for their firm, 2 means that they don't agree that given idea is a barrier, 3 means they don't agree or disagree, 4 means they agree that the given idea is a barrier for usage of digital marketing and 5 means they strongly agree that the given idea is a barrier for usage of digital marketing.

\begin{tabular}{|l|l|l|l|l|l|l|l|l|l|}
\hline & $\begin{array}{l}\text { Lack of } \\
\text { Human } \\
\text { Resources }\end{array}$ & $\begin{array}{l}\text { Lack of } \\
\text { Time }\end{array}$ & $\begin{array}{l}\text { Lack of } \\
\text { Knowledge }\end{array}$ & $\begin{array}{l}\text { Difficulty } \\
\text { of } \\
\text { Content } \\
\text { Creating }\end{array}$ & $\begin{array}{l}\text { Difficulty } \\
\text { of } \\
\text { Control }\end{array}$ & $\begin{array}{l}\text { Lack } \\
\text { of } \\
\text { Budget }\end{array}$ & $\begin{array}{l}\text { Not } \\
\text { Matching } \\
\text { Business } \\
\text { Goals }\end{array}$ & $\begin{array}{l}\text { Lack of } \\
\text { Technical } \\
\text { Support }\end{array}$ & $\begin{array}{l}\text { Resistance } \\
\text { of } \\
\text { Management }\end{array}$ \\
\hline 1 & 16,0 & 18,0 & 10,0 & 8,0 & 14,0 & 12,0 & 14,0 & 18,0 & 26,0 \\
\hline 2 & 28,0 & 18,0 & 4,0 & 12,0 & 22,0 & 20,0 & 16,0 & 16,0 & 10,0 \\
\hline 3 & 6,0 & 10,0 & 14,0 & 16,0 & 14,0 & 8,0 & 22,0 & 14,0 & 22,0 \\
\hline 4 & 32,0 & 34,0 & 26,0 & 48,0 & 38,0 & 36,0 & 36,0 & 34,0 & 20,0 \\
\hline 5 & 18,0 & 20,0 & 46,0 & 16,0 & 12,0 & 24,0 & 12,0 & 18,0 & 22,0 \\
\hline Mean & 3,08 & 3,20 & 3,94 & 3,52 & 3,12 & 3,40 & 3,16 & 3,18 & 3,02 \\
\hline
\end{tabular}

Table 4. Frequencies Table II

Correlation explains the relationship between given questions. For this study, each question has been numbered from 1 to 9. In the columns section, questions have been written and given numbers. For example; "Measurement of digital marketing is perceived as important in our firm" is number one. In the rows section, instead of rewriting the same questions, numbers are used. Row with the 1 number represents "Measurement of digital marketing is perceived as important in our firm".

Correlation is expanding from -1 to +1 . The value of -1 means very strong negative correlation, values closer to 0 means weak correlation and values closer to +1 means strong positive correlation. 


\begin{tabular}{|c|c|c|c|c|c|c|c|c|c|c|c|}
\hline & & & 1 & 2 & 3 & 4 & 5 & 6 & 7 & 8 & 9 \\
\hline \multirow[t]{18}{*}{$\begin{array}{l}\text { Spearman's } \\
\text { rho }\end{array}$} & \multirow{2}{*}{$\begin{array}{l}\text { Measurement of } \\
\text { digital marketing } \\
\text { is perceived as } \\
\text { important in our } \\
\text { firm (1). }\end{array}$} & $\begin{array}{l}\text { Correlation } \\
\text { Coefficient }\end{array}$ & 1,000 & ,695 &, 589 & ,757 &, 670 & ,493 & ,437 &, 641 &, 473 \\
\hline & & $\begin{array}{l}\text { Sig. (2- } \\
\text { tailed) }\end{array}$ & . &, 000 &, 000 & ,000 &, 000 &, 000 & ,002 & , 000 &, 001 \\
\hline & \multirow{2}{*}{$\begin{array}{l}\text { Our firm } \\
\text { measures the } \\
\text { results of digital } \\
\text { marketing against } \\
\text { objectives (2). }\end{array}$} & $\begin{array}{l}\text { Correlation } \\
\text { Coefficient }\end{array}$ & ,695 & 1,000 & ,552 & 608 &, 557 & ,411 & ,480 & ,578 &, 447 \\
\hline & & $\begin{array}{l}\text { Sig. (2- } \\
\text { tailed) }\end{array}$ &, 000 & . &, 000 & ,000 &, 000 &, 003 &, 000 & ,000 &, 001 \\
\hline & \multirow{2}{*}{$\begin{array}{l}\text { The use of digital } \\
\text { marketing has } \\
\text { changed the } \\
\text { measurement } \\
\text { practice of our } \\
\text { marketing } \\
\text { communications } \\
\text { effectiveness(3). }\end{array}$} & $\begin{array}{l}\text { Correlation } \\
\text { Coefficient }\end{array}$ & ,589 &, 552 & 1,000 & ,689 & ,649 &, 395 & ,367 & ,542 &, 591 \\
\hline & & $\begin{array}{l}\text { Sig. (2- } \\
\text { tailed) }\end{array}$ &, 000 &, 000 & . & ,000 &, 000 &, 005 & ,009 &, 000 &, 000 \\
\hline & \multirow{2}{*}{$\begin{array}{l}\text { Our firm has } \\
\text { obtained } \\
\text { measurable } \\
\text { benefits from the } \\
\text { use of digital } \\
\text { marketing (4). }\end{array}$} & $\begin{array}{l}\text { Correlation } \\
\text { Coefficient }\end{array}$ & ,757 & ,608 & ,689 & 1,000 &, 756 &, 534 & ,458 & ,670 &, 547 \\
\hline & & $\begin{array}{l}\text { Sig. (2- } \\
\text { tailed) }\end{array}$ &, 000 &, 000 &, 000 & . &, 000 &, 000 & ,001 & ,000 &, 000 \\
\hline & \multirow{2}{*}{$\begin{array}{l}\text { Efficient } \\
\text { information was } \\
\text { obtained by } \\
\text { analyzing the web } \\
\text { site visitors (5). }\end{array}$} & $\begin{array}{l}\text { Correlation } \\
\text { Coefficient }\end{array}$ & ,670 &, 557 & ,649 & ,756 & 1,000 &, 581 & ,596 & ,669 & ,623 \\
\hline & & $\begin{array}{l}\text { Sig. (2- } \\
\text { tailed) }\end{array}$ &, 000 &, 000 &, 000 & ,000 & . &, 000 &, 000 & ,000 &, 000 \\
\hline & \multirow{2}{*}{$\begin{array}{l}\text { The relevant } \\
\text { online discussions } \\
\text { and forums in our } \\
\text { field of work are } \\
\text { followed (6). }\end{array}$} & $\begin{array}{l}\text { Correlation } \\
\text { Coefficient }\end{array}$ & ,493 & ,411 & ,395 & ,534 &, 581 & 1,000 & ,813 &, 826 &, 605 \\
\hline & & $\begin{array}{l}\text { Sig. (2- } \\
\text { tailed) }\end{array}$ &, 000 &, 003 &, 005 & ,000 &, 000 & . & ,000 & ,000 &, 000 \\
\hline & \multirow{2}{*}{$\begin{array}{l}\text { Online } \\
\text { discussions and } \\
\text { forums about our } \\
\text { firm, our products } \\
\text { or services are } \\
\text { followed ( } 7) \text {. }\end{array}$} & $\begin{array}{l}\text { Correlation } \\
\text { Coefficient }\end{array}$ & ,437 &, 480 & ,367 & ,458 &, 596 &, 813 & 1,000 & 694 &, 585 \\
\hline & & $\begin{array}{l}\text { Sig. (2- } \\
\text { tailed) }\end{array}$ &, 002 &, 000 & ,009 & ,001 &, 000 &, 000 & . & ,000 &, 000 \\
\hline & \multirow{2}{*}{$\begin{array}{l}\text { Web analysis is } \\
\text { used to attract } \\
\text { new customers } \\
(8) \text {. }\end{array}$} & $\begin{array}{l}\text { Correlation } \\
\text { Coefficient }\end{array}$ & ,641 &, 578 &, 542 & 670 & 669 &, 826 & ,694 & 1,000 & ,633 \\
\hline & & $\begin{array}{c}\text { Sig. (2- } \\
\text { tailed) }\end{array}$ &, 000 &, 000 &, 000 &, 000 &, 000 &, 000 & ,000 & . &, 000 \\
\hline & $\begin{array}{l}\text { We use tools like } \\
\text { Google Alerts, }\end{array}$ & $\begin{array}{l}\text { Correlation } \\
\text { Coefficient }\end{array}$ & ,473 &, 447 & ,591 & ,547 & ,623 & ,605 &, 585 & ,633 & 1,000 \\
\hline & $\begin{array}{l}\text { Hootsuite to track } \\
\text { internet news and } \\
\text { discussions (9). }\end{array}$ & $\begin{array}{r}\text { Sig. }(2- \\
\text { tailed) }\end{array}$ &, 001 &, 001 &, 000 & ,000 &, 000 &, 000 & ,000 &, 000 & . \\
\hline
\end{tabular}

Table 5. Correlation Table

\section{Results and Discussions}

Results show that; managers perceive "Lack of Knowledge" as the biggest barrier for the usage of digital marketing as \%46 of managers strongly agree that Lack of Knowledge is a barrier for usage of digital marketing. $\% 72$ of managers either agree or strongly agree that "Lack of Knowledge" is the biggest barrier for the usage of digital marketing. This means; managers still don't have a sufficient knowledge on how to switch from classic marketing to digital marketing. Managers with the percent of \%16 'strongly' think that "Difficulty of Content Creating" creates barrier for the usage of digital marketing. This is not a very high percent but $\% 48$ of managers agree that "Difficulty of Content Creating" is a barrier for the usage of digital marketing. Summing up these two values; \%64 of managers strongly agree or agree that that "Difficulty of Content Creating" creates barrier for the usage of digital marketing. "Lack of Knowledge" also has the highest 5 scale likert mean value with 3.93 which means it is perceived as the most powerful effect as the barrier for the usage of digital marketing.. "Resistance of management" has the least mean value with 3.02 which means it is perceived as the least powerful effect as the barrier for the usage of digital marketing.

Analyzing the correlations table; "Web analysis is used to attract new customers" and "The relevant online discussions and forums in our field of work are followed" has the highest correlation with \%82,6. Respondents who use web analysis to attract new customers are also following online discussions and forums. "Online discussions and forums about our firm, our products or services are followed" and "The relevant online discussions 
and forums in our field of work are followed" has the second highest percent with \%81,3. "Measurement of digital marketing is perceived as important in our firm" and "Our firm has obtained measurable benefits from the use of digital marketing" has the third highest percent with \%75,7. "Efficient information was obtained by analyzing the web site visitors" and "Our firm has obtained measurable benefits from the use of digital marketing" has the fourth highest correlation and the last correlation to exceed $\% 70$ percent level with $\% 75,6$.

According to Table 4. "Measurement of digital marketing is perceived as important in our firm" is \%34 strongly agreed, $\% 44$ agreed and as a total $\% 78$ agreed or strongly agreed by respondents and also has 4.00 mean value which is equal to 'agree' value for 5 likert scale. This question is the strongest suggestion among all with the highest agreement rate and highest mean. "Our firm measures the results of digital marketing against objectives" has total of \%64 agree and strongly agree rate and 3.59 mean. "The use of digital marketing has changed the measurement practice of our marketing communications effectiveness" has a \%56 agree or strongly agree percent and 3.49 mean. "Our firm has obtained measurable benefits from the use of digital marketing" has \%64 agree or strongly rate and has a mean of 3.66. "Efficient information was obtained by analyzing the web site visitors" has a \%66 agree or strongly agree percent and 3.53 mean. "The relevant online discussions and forums in our field of work are followed" has a \%58 agree or strongly agree percent and a 3.3 mean. "Online discussions and forums about our firm, our products or services are followed" " has a \%58 agree or strongly agree percent and a 3.43 mean. "Web analysis is used to attract new customers" has a \%54 agree or strongly agree percent and a 3.40 mean. "We use tools like Google Alerts, Hootsuite to track internet news and discussions" has the least agreement rate with $\% 40$ agree or strongly agree percent and also the least mean with 2.83 .

According to all the tables conducted from the analysis; managers perceive measurement of digital marketing important and see lack of knowledge and difficulty of content creating as the biggest barriers for using digital marketing.

\section{References}

- Barassi, V. and Treré, E. (2012). Does Web 3.0 come after Web 2.0? Deconstructing Theoretical Assumptions Through Practice. New media and society, 14(8), 1269-1285.

- Dibb, S. Simkin, L. William M.P., Ferrell, O.C. (2012). Marketing Concepts and Strategıes, 6th Edition, Cengage Learning EMEA.

- Fill, C. (2006). Simply Marketing Communications, Pearson Education Limited, England.

- Järvinen, J. Tollinen, A., Karjaluoto, H., and Jayawardhena, C. (2012). Digital And Social Media Marketing Usage In B2b Industrial Section. Marketing Management Journal, 22(2).

- Kingsnorth, S. (2016). Digital Marketing Strategy - An Integrated Approach to Online Marketing. Kopan Page.

- Kotler, P. Armstrong, G. (2014). Principles of Marketing, 15th Global Edition, Pearson Education Limited, England.

- Öçal, A. (2011). Dijital Pazarlama Nedir? Teknikleri Nelerdir?, İstanbul.

- $\quad$ Tiago, M. T. P. M. B. and Veríssimo, J. M. C. (2014). Digital Marketing and Social Media: Why Bother? Business Horizons, 57(6), 703-708. 